\title{
The Impact of Guided Inquiry Model Integrated with Peer Instruction towards Science Process Skill and Physics Learning Achievement
}

\author{
Hestiningtyas Yuli Pratiwi ${ }^{1}$, Muhammad Nur Hudha ${ }^{1 *}$, Mathilda Asri ${ }^{1}$, Nur Jahan Ahmad ${ }^{2}$ \\ ${ }^{1}$ Physics Education Study Program, Faculty of Science and Technologi, Universitas Kanjuruhan Malang, Indonesia \\ 2 School of Educational Studies, Universiti Sains Malaysia, Malaysia \\ *Corresponding Author. E-mail: muhammadnurhudha@unikama.ac.id
}

\begin{abstract}
The aim of the research is to find out the difference in science process skill and learning achievement between students who are taught using guided inquiry model integrated with peer instruction and conventional method in VII students in one of the junior high schools in Malang. The method used is quasy-experimental with only post-test group design. The sample was selected using purposive sampling technique, from the 10 population of VII grade students; the researchers selected two classes which were considered to have the same initial skill with total 32 students in each class to be the experimental class and the control class. Instruments used were the observation sheets to measure the science process skill and the test of multiple choices to measure the learning achievement. The researchers gained average score of 81 for science process skill in experimental class and 58 in control class, while the average score of 77.8 for learning achievement in experimental class and 71.3 in control class as the result of the data analysis. The hypothesis test used T-test, that was the independent sample T-test on Microsoft excel by looking up the score of Ttable on the rate of sig 0.05 for the science process skill and it gained Tcount $>$ Ttable $(18.846>1.669)$, while the learning process gained Tcount $>$ Ttable $(8.465$ $>1.669$ ). It was concluded that the guided inquiry model integrated with peer instruction can improve student's science process skill and learning achievement compared to conventional method.
\end{abstract}

Keywords: Guided inquiry; learning achievements; peer instruction; science process skill.

\section{Introduction}

Education is a place to create qualified Human Resource who can think innovatively and optimally in mastering knowledge in order to be able to compete and survive in globalization era which develops rapidly (Arifin, 2018). It agrees with a statement which states knowledge has dominant role in global society, that school education must have good quality and be able to compete with other country's education (Subekti, Taufiq, Susilo, Ibrohim, \& Suwono, 2018). Physics is one of school subjects which is considered as difficult to understand by students of high school. The literature is strengthened by some previous researches, they are researches which were conducted in State Junior High 1 Pegajahan by giving questionnaire to 34 students, with 21 students said physics was difficult and 13 students said the physics learning process was boring and less interesting (Damawiyah, 2015); and the result of limited interview towards students one of Senior High School in Jember which stated that the students felt bored of monotonous learning process (Fitasari, Bektiarso, \& Subiki, 2018).

The result shows the learning process did not develop scientific attitude, such as curiosity, honesty, responsibility, seriousness, and open minded in accepting other's opinion based on certain evidences in order not to create bored situation during class (Asmawati, 2015); (Nurhudayah \& Lesmono, A, 2016). In order to develop scientific attitude for students, then one of purposes in learning physics is develop the skill

How to Cite:

Pratiwi, H., Hudha, M., Asri, M., \& Ahmad, N. (2019). The Impact of Guided Inquiry Model Integrated with Peer Instruction towards Science Process Skill and Physics Learning Achievement. Momentum: Physics Education Journal, 3(2), 78-85. https://doi.org/10.21067/mpej.v3i2.2768 
of thinking and taking act based on possessed scientific knowledge or generally known as science process skill (Suwandari, Muhamad, \& Rahayu, 2018).

Science process skill is a skill to develop scientific attitude to find concept, principle, or theory (Nurhudayah \& Lesmono, A, 2016). New concept or theory which is found in science process skill is used to deny the previous finding and to develop the student's cognitive skill so the essence of physics becomes whole. In fact, the result of the research stated that the science process skill of students in some observed schools was still low. It happened because most learning process still concentrated on teachers with conventional methods as giving speech, giving demonstration, and making notes. Conventional methods cannot fully develop student's science process skill.

Besides science process skill, the teacher's purpose in learning is to improve student's achievement in learning physics. Learning achievement is the result accepted by students during learning process which has been conducted. Physics learning achievement in Indonesia is still considered low. It can be seen from the data of the previous researcher who also spread questionnaires to students; the result was $41.1 \%$ students of all observed students got below average score in physics and the result of learning achievement observation for mid-term test of class $X$ of Budi Mulia Vocational High Pakisaji which did not meet the standard of minimum score, it was $66.67 \%$.

Base on the explanation above, it needs a learning model which can improve student's science process skill and physics learning skill to solve the problem. The solution is to use the correct learning model, it is guided inquiry learning model (Aji, Bernadino, \& Hudha, 2017). Guided inquiry learning model is a learning model which concentrates on students in finding their own concepts or information by teachers giving opportunity to students as well as guiding them (Wartono, Hudha, \& Batlolona, 2018).

The purpose of learning using guided inquiry approach is to improve intellectual skill and to solve learning conflict scientifically that it will change student's learning habit from waiting for teachers to give them knowledge to meaningful learning (Aji et al., 2017). Apparently the implementation of guided inquiry model there were still students who were less active in learning due to noisy class and lack of effort during learning (Kurniawati \& Diantoro, 2014). To solve the problem, thus it needs combination between guided inquiry learning model and another learning model o method. One of effective and suitable learning models to optimize physics learning activity is peer instruction (Mahardika, 2016).

Peer instruction can help students being active in learning process and improve student's mastering physics concept (Puspitasari, Pasaribu, \& Kendek, 2017). Here the student becomes tutor to help his/her friend learn (Sari \& Aisyah, 2016). Peer instruction learning will be interspersed with concept questions so all students can participate to be active during class. The effectiveness of peer instruction learning is proven by the previous research which concluded that there is influence towards the student's learning achievement.

The integration between these model and method in each phase affects student's science process skill and learning achievement. Fourth phase is to collect data by peer and fifth phase is to test hypothesis by peer, will give big positive influence towards science process skill through activity of experimenting, collecting, and analyzing experiment result, and discussing concept test, while second phase is to formulate problem by peer and seventh phase feedback has big influence towards student's learning achievement through activity of thinking the concept test answers, experiment result and concept test confirmation, model worksheet and evaluation worksheet which can improve student's intellectual skill.

\section{Methods}

Method used in the research was quasy-experimental with post-test only control group design. The research method is on the Table 1. 
Table 1. Post-test Only Control Group Design

\begin{tabular}{ccc}
\hline Group & Treatment & Post-test \\
\hline Experiment & $\mathrm{X}_{1}$ & $\mathrm{~T}_{2}$ \\
Control & $\mathrm{X}_{2}$ & $\mathrm{~T}_{2}$ \\
& {$[20]$} & \\
\hline
\end{tabular}

Explanation:

$\mathrm{X}_{1}$ : giving treatment to experimental class using guided inquiry model integrated with peer instruction

$\mathrm{X}_{2}$ : giving treatment to control class using conventional learning method

$\mathrm{T}_{2}$ : post-test for experimental and control groups

The research consisted of two groups of classes, they were experimental class which taught by guided inquiry model integrated with peer instruction and control class which taught by conventional learning model. The population was VII Students of State Junior High 1 Kepanjen which consisted of 10 classes. Sample was taken using sampling purposive technique that resulted two classes, they were VII D and VII E which were considered to have the same initial skill observed from report score and test score of Science Subject; VII D with 32 students as the experimental class and VII E with 32 students as the control class.

There were two instruments used in the research; the science process skill used data of observation result during treatment while the learning achievement used test in the form of multiple choices after treatment. Then the result data was tested by normality and homogeneity. After it was normally distributed and had the same variant, then it was hypothetically tested. The hypothesis test in the research used parametric statistics discipline to find out the different treatments between experimental class and control class. The technique used in the hypothesis test was T-test analysis technique; it was the independent sample T-test for the same samples and variants with formula as the following:

$t=\frac{\bar{x}_{1}-\bar{x}_{2}}{\sqrt{\frac{s_{1}^{2}}{n_{1}}+\frac{s_{2}^{2}}{n_{2}}}}$

Explanation:

$\mathrm{X}_{1} \quad=$ sample 1 average

$\mathrm{X}_{2} \quad=$ sample 2 average

$\mathrm{S}_{1}{ }^{2} \quad=$ sample 1 variation

$\mathrm{S}_{2}{ }^{2} \quad=$ sample 2 variation

$\mathrm{N}_{1} \quad$ = sample 1 standard deviation

$\mathrm{N}_{2} \quad$ = sample 2 standard deviation

The background of decision making is as follow:

1. If $F_{\text {count }}>F_{\text {table, }}$ thus data is significant; it means there is different science process skill between students taught using guided inquiry model integrated with peer instruction and students taught using conventional method. If $F_{\text {count }}<F_{\text {table, }}$ thus data is not significant; it means there is no different science process skill between students taught using guided inquiry model integrated with peer instruction and students taught using conventional method.

2. If $F_{\text {count }}>F_{\text {table, }}$ thus data is significant; it means there is different learning achievement between students taught using guided inquiry model integrated with peer instruction and students taught using conventional method. If $F_{\text {count }}<F_{\text {table, }}$ thus data is not significant; it means there is no different learning achievement between students taught using guided inquiry model integrated with peer instruction and students taught using conventional method. 


\section{Result and Discussion}

\subsection{Result}

\subsubsection{Data Description}

Data collected in the research was data of science process skill collected by students during treatment while data of learning achievement collected by students after treatment. It was collected from data of observation result for science process skill and written test (multiple choices) for learning achievement. Data of science process skill was collected using instrument for science process skill and learning achievement which have been validated by supervisor of Physics Education Major, Faculty of Science and Technology, Kanjuruhan University Malang.

The test instrument of learning achievement was validated not only for the content but also for the construction, and was applied to VII students of State Junior High 1 Kepanjen. The test instrument data of student's learning achievement was validated for the problems with correlation formula of Karl Person by comparing score $r_{\text {table }}$ and $r_{\text {count. If }} r_{\text {table }}>r_{\text {count }}$ then the problems are valid. The result was that the validated 20 problems were proper to test the student's learning achievement. The validation rate can be seen from the data with 6 problems which are validated as low with average score of $0.34-0.39$; however there are 14 problems which are validated as quite with average score of $0.40-0.59$.

Then those problems were tested for the reliability. It came with high score of reliability that the 20 problems have high rate of reliability. It can be seen on Table 2 for clearer information.

Table 2. Reliability Instrument Test

\begin{tabular}{llll}
\hline Test & Rkr20 & $r_{\text {table }}$ & Explanation \\
\hline Reliable & 0.77 & 0.33 & High reliability \\
\hline
\end{tabular}

Table 2 shows that there were score of $r_{\text {count }}$ and $r_{\text {table }}$ in the test of reliability instrument; because $r_{\text {count }}$ was 0.77 and $r_{\text {table }}$ was 0.33 then it is in high reliability rate.

Then they were tested for the difference capacity to differ the upper and under class. Those 20 problems, there are 2 problems of medium category with score $0.22,3$ problems of high category with score 0.33 , and 15 problems of very high category with score $0.4-0.55$. Next, they were tested for the difficulty rate; they are in rate of medium and low difficulty. Thus, the problems can be done by all students in upper and under class. The results of the problem meet all the requirements that they can be used to test the student's cognitive skill both in experimental class and control class.

The research used sampling purposive technique. Both classes which would be the sample of the research must have the same initial average class score. The descriptive calculation result of student's science process skill was collected during treatment both in experimental class and control class. The data collected used the data of observation result by two researchers. There were 6 dimensions of science process skill collected with the same core for each group. The data description of 64 students' science process skill in experimental class and control class can be seen in Table 3.

Table 3. Data of Student's Science Process Skill Score

\begin{tabular}{|c|c|c|c|c|c|}
\hline \multirow[t]{2}{*}{ Class } & \multirow[t]{2}{*}{ Learning Model } & \multirow{2}{*}{$\begin{array}{l}\text { Sample } \\
\text { amount }\end{array}$} & \multicolumn{2}{|c|}{$\begin{array}{l}\text { Student's science process skill } \\
\text { score }\end{array}$} & \multirow[t]{2}{*}{ Average } \\
\hline & & & Highest & Lowest & \\
\hline Experimental & $\begin{array}{l}\text { Inquiry model integrated with peer } \\
\text { instruction }\end{array}$ & 32 & 92,7 & 68,6 & 81,6 \\
\hline Control & Conventional & 32 & 64,8 & 46,2 & 59,0 \\
\hline
\end{tabular}

Data of student's learning achievement in experimental class and control class was collected after treatment through post-test using learning achievement test in the form of multiple choices. The data description for learning achievement of 32 students of experimental class and 32 students of control class 
can be seen in Table 4. Table 4 shows that experimental class gained average class score of 78 while control class gained average class score of 71. It means experimental class got higher score than control class did with a difference of 7 .

Table 4. Data of Student's Learning Achievement Score

\begin{tabular}{|c|c|c|c|c|c|}
\hline \multirow[t]{2}{*}{ Class } & \multirow[t]{2}{*}{ Learning model } & \multirow{2}{*}{$\begin{array}{l}\text { Sample } \\
\text { amount }\end{array}$} & \multicolumn{2}{|c|}{$\begin{array}{l}\text { Student's initial skill } \\
\text { score }\end{array}$} & \multirow[t]{2}{*}{ Average } \\
\hline & & & Highest & Lowest & \\
\hline Experimental & $\begin{array}{l}\text { Inquiry model integrated with peer } \\
\text { instruction }\end{array}$ & 32 & 95 & 40 & 78 \\
\hline Control & Conventional & 32 & 90 & 45 & 71 \\
\hline
\end{tabular}

\subsubsection{Hypothesis Test Result}

Before the hypothesis test, there were requirements to meet; data must be normally distributed and must be from homogenous groups. The analysis test for normally distributed used lilliefors test while data of homogenous groups used bartltet test on Microsoft excel 2010. The result data of normality test for student's science process skill shows that the experimental class gained $\mathrm{L}_{\text {count }}<\mathrm{L}_{\text {table }}(0.149<0.16)$ while the control class gained $L_{\text {count }}<L_{\text {table }}(0.143<0.16)$; and the result data for student's learning achievement of the experimental class gained $L_{\text {count }}<L_{\text {table }}(0.142<0.16)$ while the control class gained $L_{\text {count }}<L_{\text {table }}(0.145<$ 0.16). It meant the data of student's science process skill and learning achievement both in experimental class and control class were normally distributed. The data of homogeneity test for science process skill gained $T_{\text {count }}<T_{\text {table }}(0.104<3.841)$ and it gained $T_{\text {count }}<T_{\text {table }}(0.00<3.841)$ for student's learning achievement that data collected from both experimental class and control class were from homogenous groups.

Besides, the result of the same initial skill test between students of the experimental class and control class can be seen in Table 5 .

Table 5. Result of the Same Initial Skill Test

\begin{tabular}{lll}
\hline Score & $T_{\text {count }}$ & $T_{\text {table }}$ \\
\hline Student's initial skill & 0.0003 & 1.669 \\
\hline
\end{tabular}

Table 5 shows that the students' initial skills between experimental class and control class were the same. It can be seen from $T_{\text {count }}<T_{\text {table }}$ with the result of $0.0003<1.669$.

The hypothesis test in the research was the T-test (Independent Sample T-Test) with the assistance of Microsoft excel 2010. The hypothesis would be accepted if $T_{\text {count }}$ score was higher than $T_{\text {table }}\left(T_{\text {count }}>T_{\text {table }}\right)$ while the hypothesis would be rejected if $T_{\text {count }}$ score was lower than $T_{\text {table }}$ ( $\left.T_{\text {count }}<T_{\text {table }}\right)$. The result of hypothesis test used Independent Sample T-Test by comparing the scores of $T_{\text {count }}$ and $T_{\text {table }}$ which can be seen in Table 6 and 7.

Table 6. Result of Hypothesis Test in Student's Science Process Skill

\begin{tabular}{lll}
\hline Source of variant & $T_{\text {count }}$ & $T_{\text {table }}$ \\
\hline Student's science process skill & 18.846 & 1.6698
\end{tabular}

Table 6 shows that the student's science process skill was $T_{\text {count }}>T_{\text {table }}(18.846>1.6698)$. It means the result of statistic test on hypothesis test using independent sample T-test shows the difference in science process skill between students who were taught by guided inquiry model integrated with peer instruction and conventional method.

Table 7. Result of Hypothesis Test in Student's Learning Achievement

\begin{tabular}{cll}
\hline Source of variant & $T_{\text {count }}$ & $T_{\text {table }}$ \\
\hline Post-test of student's learning achievement & 8.465 & 1.6698 \\
\hline
\end{tabular}


Table 7 shows that the student's learning achievement was $T_{\text {count }}>T_{\text {table }}(8.465>1.6698)$. It means the result of statistic test on hypothesis test using independent sample T-test shows the difference in learning achievement between students who were taught by guided inquiry model integrated with peer instruction and conventional method.

\subsection{Discussion}

The researchers gained $T_{\text {count }}(18.86)>T_{\text {table }}$ (1.6698) as the result of hypothesis analysis through independent sample T-test. The analysis result shows that there was difference in science process skill between students who were taught by guided inquiry model integrated with peer instruction and conventional method. It shows that the experimental class gained better score than the control class did.

The researchers found out the result of statistic test in the research shows that the guided inquiry model integrated with peer instruction affected the student's science process skill. The indicators of science process skill measured in the research were observing, giving questions, formulating hypothesis, doing lab work, presenting data, and applying concept. The series in each phase of guided inquiry learning can train the aspects of science process skill. It is supported by the previous research which concluded that the guided inquiry model can improve he student's science process skill (Nuryadin \& Delinda, 2018).

The science process skill will grow and be easily developed towards students if they are treated using guided inquiry model integrated with peer instruction because each phase of the learning teaches the aspects of science process skill. Peer instruction along with concept questions and discussion between partners will help students in groups to relate the result of lab work with the learning concept implemented that it will ease them to apply the concept through decision making. The answers of concept test found by students themselves will be kept in their memory for a long time (Juhji, 2016).

The researchers gained $T_{\text {count }}(8.46)>T_{\text {table }}(1.6698)$ as the result of hypothesis test for the learning achievement through independent sample T-test. The analysis result shows that there as difference in learning achievement between students who were taught by guided inquiry model integrated with peer instruction and conventional method. The post-test result of learning achievement shows that the experimental class gained better score than the control class.

Activity conducted in the research which could improve the student's learning achievement was in the observation phase where students given opportunity to think for the answers of the concept test from the teacher then discussing them with their partners in the hypothesis test phase. The concept test given by teacher could stimulate students to understand the concepts in learning more so students could explore the answers of the concept tests (Pratiwi, Winarko, \& Ayu, 2018). Concept explored by the students with their partners will be recorded in their mind for a longer time (Tangkas, 2012). Besides, the feedback phase of the guided inquiry model integrated with peer instruction can improve the student's knowledge through the confirmation of concept test answers and result of lab work, solving problems together with partners, and doing evaluation test given in each end of meetings which could improve the student's cognitive skill so they could understand the subject more.

The result of student's initial skill test shows that the average class score for experimental class has improved. While the control class which was treated using conventional method experienced a little decreasing average class score. The different result of learning achievement between the experimental class and the control class was because the guided inquiry model integrated with peer instruction gave students opportunity to be active in learning by discussing with their partners in many organized phases so the learning process became effectively meaningful. The interactions through peer instruction activity will help the students who hesitate and are afraid to ask the teacher that all their hesitation will be responded when they are given opportunity to discuss with their friends (Pratiwi, $\mathrm{H}, 2016$ ) so the activity can improve the student's learning achievement. 
Conventional learning method considers all students to have been ready in joining the learning. In this method teachers dominate the learning process that the students are not active in it. It means the guided inquiry model integrated with peer instruction give good impact to improve student's learning achievement. The result of the research is also supported by the result of the previous research that the guided inquiry model integrated with peer instruction could improve the student's concept mastering and critically thinking (Kurniawati \& Diantoro, 2014), while the result of research using the guided inquiry model integrated with peer instruction has significant impact towards student's learning achievement (Puspitasari et al., 2017).

\section{Conclusion}

The conclusion of the research is there is difference in science process skill and learning achievement between students who were taught by guided inquiry model integrated with peer instruction and conventional learning method. Based on the explanation of the result, the researchers suggest that the guided inquiry model integrated with peer instruction is very suitable to implement in science learning. Therefore, the researchers hope to conduct further test towards the guided inquiry model integrated with peer instruction with the same or different subject and to plan optimal time so that the learning activity becomes effective and efficient.

\section{Reverences}

Aji, S. D., Bernadino, A., \& Hudha, M. N. (2017). Inkuiri terbimbing dengan pendekatan saintifik (Scientific approach) untuk meningkatkan berpikir kritis. Momentum: Physics Education Journal, 1(2), 140. https://doi.org/10.21067/mpej.v1i2.2148

Arifin, I. (2018). Nilai-nilai humanistik dalam peningkatan mutu pendidikan di era globalisasi dan revolusi industri 4.0. Administrasi Pendidikan Dan Manajemen Pendidikan, pp. 1-9.

Asmawati. (2015). Lembar Kerja Siswa (LKS) Menggunakan model guaded inkuiri untuk meningkatkan keterampilan berpikir kritis dan penguasaan konsep siswa. Jurnal Pendidikan Fisika.

Damawiyah, I. (2015). Pengaruh Model pembelajaran inkuiri terbimbing terhadap hasil belajar siswa pada materi pokok usaha dan energi di SMPN 1 Panggajahan. J. Inpafi, 3(2), 182-190.

Fitasari, N., Bektiarso, S., \& Subiki. (2018). Penerapan model pembelajaran inkuiri terbimbing dilengkapi LKS untuk mengetahui keterampilan proses sains dan prestasi belajar pada materi pokok hukum dasar kimia siswa kelas X MIA 4 SMA N 1 Karanganyar tahun pelajaran 2014/2015. Seminar Nasional Pendidikan Fisika, 3, 95-102.

Juhji, J. (2016). Peningkatan keterampilan proses sains siswa melalui pendekatan inkuiri terbimbing. Jurnal Penelitian Dan Pembelajaran IPA. https://doi.org/10.30870/jppi.v2i1.419

Kurniawati, I. D., \& Diantoro, M. (2014). Pengaruh Pembelajaran inkuiri terbimbing integrasi peer instruction terhadap penguasaan the effect of peer instruction integrated guided inquiry learning on concepts acquisition and critical thinking of students. Jurnal Pendidikan Fisika Indonesia (Indonesian Journal of Physics Education). https://doi.org/10.15294/jpfi.v10i1.3049

Mahardika, I. K. (2016). Model Inkuiri terbimbing integrasi peer instruction disertai LKS berbasis multirepresentasi terhadap kemampuan representasi verbal dan matematika. Seminar Nasional Pendidikan 2016, 1, 555-563.

Nurhudayah, M., \& Lesmono, A, D. (2016). Penerapan model inkuiri terbimbing (Guided inquiry) dalam pembelajaran fisika SMA di Jember ( Studi pada keterampilan proses sains dan keterampilan berpikir kritis). Jurnal Pembelajaran Fisika, 5(1), 82-88.

Nuryadin, E., \& Delinda, D. (2018). Pengaruh inkuiri terbimbing (guided inquiry) terhadap keterampilan proses sains dasar peserta didik pada materi sistem ekskresi manusia. Jurnal Pelita Pendidikan. https://doi.org/10.24114/jpp.v6i4.11168

Pratiwi, H, Y. (2016). Pengaruh strategi konflik kognitif dengan tutorial sebaya terhadap penguasaan konsep 
fisika ditinjau dari kemampuan penalaran ilmiah siswa kelas X SMAN 1 Singosari. Jurnal Riset Pendidikan Fisika, 1(1).

Pratiwi, H. Y., Winarko, W., \& Ayu, H. D. (2018). The impact of problem solving strategy with online feedback on students' conceptual understanding. Journal of Physics: Conference Series, 1006(1). https://doi.org/10.1088/1742-6596/1006/1/012024

Puspitasari, D., Pasaribu, M., \& Kendek, Y. (2017). Pengaruh model pembelajaran inkuiri terbimbing berbasis peer instruction terhadap hasil belajar fisika siswa kelas X SMA Negeri 2 Sigi. JPFT (Jurnal Pendidikan Fisika Tadulako Online), 5(1), 11. https://doi.org/10.22487/j25805924.2017.v5.i1.6695

Sari, R., \& Aisyah, S. (2016). Penerapan peer instruction with structured inquiry (Pisi) untuk meningkatkan hasil belajar kimia siswa. 1(2), 176-188.

Subekti, H., Taufiq, M., Susilo, H., Ibrohim, \& Suwono, H. (2018). Mengembangkan Literasi informasi melalui belajar berbasis kehidupan terintegrasi STEM untuk menyiapkan calon guru sains dalam menghadapi era revolusi industri 4.0. Educ. Hum. Dev. J., 3(1), 81-90.

Suwandari, P., Muhamad, T., \& Rahayu, S. (2018). Pengaruh model pembelajaran inkuiri terbimbing terhadap penguasaan konsep dan keterampilan proses sains fisika peserta didik kelas XI MAN 2 Mataram tahun pelajaran 2017/2018. Jurnal Pendidikan Fisika Dan Teknologi, 4(2).

Tangkas, I. (2012). Pengaruh implementasi model pembelajaran inkuiri terbimbing terhadap kemampuan pemahaman konsep dan keterampilan proses sains siswa kelas X SMAN 3 Amlapura. Jurnal Pendidikan IPA, 2(1).

Wartono, W., Hudha, M. N., \& Batlolona, J. R. (2018). Guided inquiry and PSR in overcoming students' misconception on the context of temperature and heat. AIP Conference Proceedings, 2014(September). https://doi.org/10.1063/1.5054433 